\title{
Lilia Delcheva Dodekova-Sapunova (April 26, 1934 - September 17, 2016)
}

The world-renowned and highly respected scientist studying Jurassic dinoflagellates Lilia Dodekova passed away on September 17, 2016, at the age of 82 . With her death, Bulgarian palaeontology lost not only one of its colossal workers, but also a modest and thoughtful person who earned the respect of all who knew her.

Lilia Dodekova was born on April 26, 1934, in the town of Panagyurishte. In 1952, she graduated with honours from the high school in her hometown. The same year, she began working as an accountant in the State Savings Bank (DSK) in Panagyurishte. Next year, she was accepted to Sofia University (Faculty of Biology, Geology and Geography), from where she graduated in 1958 as a Geologist-geochemist. Lilia Dodekova was appointed as field geologist at the State Committee of Geology in 1958. She worked for six years in the geological mapping associated with the oil exploration in northwestern and northern Bulgaria and with the field investigations of areas of southwestern Bulgaria. Her first published geological paper was devoted to the stratigraphy of the Aptian and Albian of the Vratsa region (NW Bulgaria). She was an author and co-author of articles on the geological and structural studies of Beshovitsa anticline (Vratsa-Mezdra area, NW Bulgaria), on the Tortonian of the Pleven region (North Bulgaria), and on the tectonic structure of parts of North Bulgaria along the area between the rivers of Iskar and Vit. Since her earliest active years, she had shown great efficiency and love for the geological profession. Then, and during the entire time of her professional career, she proved to be a well-trained expert who is familiar with, and skilfully solves, scientific problems.

Lilia Dodekova became a Research Associate in 1964 at the Research Institute of the Committee of Geology, which in 1967 merged with the Geological Institute at the Bulgarian Academy of Sciences. There, she was successfully promoted and continued working until her retirement in 1989. She undertook extramural postgraduate research on Micropaleontology in 1965 , but as events were completely outside her control, her $\mathrm{PhD}$ thesis remained unfinished. The

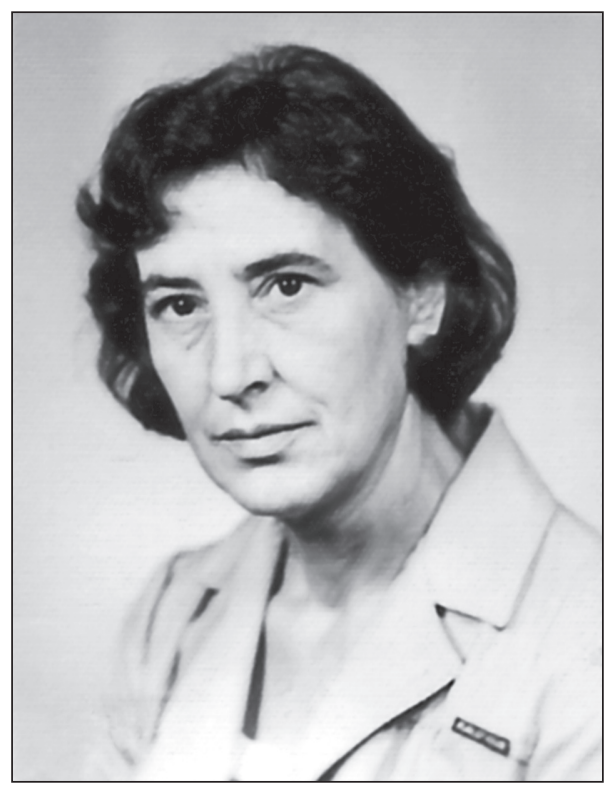

months spent in Poland in 1968, when she was on a training course on fossil dinoflagellates, were a critical landmark in her geological career. At that time, she had already made her first steps in the study of this little-known fossil group, but from the early 1970s, her scientific life had almost entirely been dedicated to the taxonomy of these fossils and their stratigraphical distribution in the Jurassic rocks. Another milestone in her career was the geological expedition in the province of Las Villas (Cuba), in which she took part in the years between 1969 and 1971. In collaboration with the eminent Bulgarian palaeontologist Vasil Zlatarski, she carried out detailed descriptions of more than 90 sections and 1,900 outcrops of the Upper Cretaceous sediments. This fruitful cooperation led to the stabilization of the formal lithostratigraphic scheme for the Upper Cretaceous in Cuba, as well as to the establishment of new units. The conclusions of this colossal work were summarized in an elaborate geological re- 
port that was highly appreciated at the Conference of the Cuban Academy of Sciences at the end of 1971. After that, Lilia Dodekova continued to work actively on various applied and scientific projects of the Geological Institute. She was a guest lecturer at a pre-graduation training of students at the University of Mining and Geology. She was technical secretary of the Organizing Committee of the International Symposium on the Jurassic/Cretaceous boundary held in Bulgaria in 1977. She was also an affiliate of the Organizing Committee of the International Symposium of the Paratethys Group in 1978. Lilia Dodekova was an active member of the Bulgarian Geological Society, as well as of the AASP (The Palynological Society).

The written heritage of Lilia Dodekova is not large, but she left valuable papers, including those in Geologica Balcanica, which have been cited and continue to be cited worldwide to date. She contributed to the Jurassic stratigraphy in the deep borehole sections in northern Bulgaria; to clarification of the stratigraphy, extents and relationships of the Jurassic lithostratigraphic units in the framework of the Balkan orogen; and especially to determining the taxonomic composi- tion of the dinoflagellate assemblages of a broad stratigraphic interval, from the Bathonian (Middle Jurassic) to the Valanginian (Lower Cretaceous). The latter has not been subdivided into an appropriate biostratigraphic scheme, but the identified taxa include many new species and genera that have since been recorded in many localities around the world. The recognition of the new taxa, based on Bulgarian material, has repeatedly been obtained by including and confirming most of them in the major catalogues and indexes of the fossil dinoflagellate cysts published in the last decades (e.g., Sarjeant, 1974; Lentin and Williams, 1977, 1981; Beaudoin and Head, 2004; Powell and Riding, 2005; Traverse, 2007). This also applies to the last electronic index of fossil dinoflagellate cysts: Dinoflaj2 (http://dinoflaj.smu.ca).

To some who met her, Lilia Dodekova may have appeared somewhat distant, but to those who knew her, she was a warm and agreeable person who never hesitated to offer help and advice to those who sought it. For my own part, I am proud to have known Lilia Dodekova and to have called her and her family friends.

Lubomir Metodiev

\section{REFERENCES}

Sarjeant, W.A.S. 1974. Fossil and living dinoflagellates. Academic Press, London, 182 pp.

Lentin, J.K, Williams, G.L. 1977. Fossil dinoflagellates: index to genera and species, 1977 Edition. Bedford Institute of Oceanography, Report Series/BI-R-77-8 July 1977, 209 pp.

Lentin, J.K, Williams, G.L. 1981. Fossil dinoflagellates: index to genera and species, 1981 Edition. Bedford Institute of Oceanography, Report Series/BI-R-81-12 August 1981, $345 \mathrm{pp}$.

Beaudoin, A.B., Head, M.J. (Eds.) 2004. The palynology and micropalaeontology of boundaries. The Geological Society of London, Special Publication No. 230, 359 pp.

Powell, A.J., Riding, L.B. (Eds.). 2005. Recent developments in applied biostratigraphy. The Geological Society of London, $253 \mathrm{pp}$.

Traverse, A. 2007. Paleopalynology (Second edition). Springer Science \& Business Media, Dordrecht, the Netherlands, $813 \mathrm{pp}$.

\section{CONTRIBUTIONS OF LILIA DODEKOVA}

Dodekova, L. 1961. Stratigraphie de l'Aptien et l'Albien dans la région de Vratsa. Annuaire de la direction générale de recherches géologiques, Série A 11, 79-99 (in Bulgarian, with French summary).

Minčev, D., Čolakov, D., Dodekova, L., Pironkov, P. Stojkov, M. 1962. Geologische und strukturelle Untersuchungen in den Bezirk von Beschovitza-stättel. Annuaire de la direc- tion générale de recherches géologiques, Série A 12, 183192 (in Bulgarian, with Russian and German abstracts).

Dodekova, L. 1962. Un nouveau gisement du Tortonien dans la région de Pleven en Bulgarie septentrionale. Review of the Bulgarian Geological Society 32 (1), 70-73 (in Bulgarian, with French summary).

Velev, V., Dodekova, L., Valceva. 1963. La tectonique de la Bulgarie septentrionale centrale dans le bassin de rivières Iskar et Vit en vue de la prospection de naphte et de gaz. Review of the Bulgarian Geological Society 24 (3), 263-274 (in Bulgarian, with French abstract).

Dodekova, L. 1968. Les dinoflagellés et acritarches de l'Oxfordien-Kimméridgien de la Bulgarie du nord-est. Annuaire de l'Université de Sofia, Faculté de géologie et géographie Livre 1, géologie, 60, 9-30, pls 1-3.

Dodekova, L. 1969. Les dinoflagellés et acritarches du Tithonique aux environs de Pleven, Bulgarie Centrale du nord. Bulletin of the Geological Institute, Series Palaeontology 18, 13-24, pls 1-5.

Dodekova, L. 1971. Dinoflagellés et acritarches du Tithonique dans la partie centrale de la Bulgarie septentrionale. Bulletin of the Geological Institute, Series Palaeontology 20, 5-22, pls 1-5 (in Bulgarian, with Russian and French summaries).

Dodekova, L. 1974. Compositosphaeridium gen. n. - a new genus dinoflagellate cyst. Bulletin of the Geological Institute, Series Palaeontology 23, 25-30, pls 1, 2.

Dodekova, L. 1975. New Upper Bathonian dinoflagellate cysts from North eastern Bulgaria. Palaeontology, Stratigraphy and Lithology 2, 17-30, pls 1-6.

Bakalova, D., Dodekova, L., Kovatcheva, T., Sapunov, I. 1976. New data on the stratigraphy of the Brestnica Formation 
(NW Bulgaria). Comptes rendus de l'Académie bulgare des Sciences 29 (9), 1321-1324.

Dodekova, L. 1981. The dinoflagellates - mysterious organisms. Priroda 2, 52-56.

Dodekova, L. 1983. Two new Bathonian organic-walled microplankton genera from Northeast Bulgaria. Palaeontology, Stratigraphy and Lithology 18, 35-41, pls 1, 2.

Dodekova, L. 1990. Dinoflagellate cysts from the BathonianTithonian (Jurassic) of North Bulgaria. I. Taxonomy of Bathonian and Callovian dinoflagellate cysts. Geologica Balcanica 20 (2), 3-45, pls 1-10.

Dodekova, L. (in Tchoumatchenco, P., Černjavska, S.). 1990. Dinoflagellate cysts in the Luda Kamchiya Group of East Stara Planina. Geologica Balcanica 20 (3), 51-52, pl. 1 (in Russian).

Dodekova, L. 1992. Dinoflagellate cysts from the BathonianTithonian (Jurassic) of North Bulgaria. II. Taxonomy of Oxfordian and Kimmeridgian dinoflagellate cysts. Geologica Balcanica 22 (3), 33-69, pls 1-10.

Dodekova, L. 1994. Dinoflagellate cysts from the BathonianTithonian (Jurassic) of North Bulgaria. III. Tithonian dinoflagellate cysts. Geologica Balcanica 24 (5), 11-46, pls $1-12$.

Dodekova, L., Čatalov, G. 1982. Dinoflagellates from the Middle Jurassic sediments in the village of Kalovo environs, Strandja Mountain. Comptes rendus de l'Académie bulgare des Sciences 35 (5), 669-672, pl. 1.

Dodekova, L., Sapunov, I., Tchoumatchenco, P. 1984. Stratigraphy of the Aalenian, Bajocian and Bathonian rocks in a part of Southwestern Bulgaria. Geologica Balcanica 14 (2), 3-55 (in Russian with English and Russian abstracts).
Lefeld, J., Sapunov, I., Tchoumatchenco, P., Bakalova, D., Dodekova, L. 1986. Upper Jurassic-lowermost Cretaceous sequences in the Inner Carpathians (Poland) and the Balkanids (Bulgaria) - a comparison. Geologica Balcanica 16 (6), 87-97.

Bakalova, D., Dodekova, L, Čemberski, H. 1982. List of names of sedimentary and volcanosedimentary lithostratigraphic units introduced in Bulgaria. Review of the Bulgarian Geological Society 43 (1), 102-112 (in Bulgarian, with English abstract).

Sapunov, I., Tchoumatchenco, P., Dodekova, L., Bakalova, D. 1985. Stratigraphy of the Callovian and Upper Jurassic rocks in southwestern Bulgaria. Geologica Balcanica 15 (2), 3-61 (in Russian, with English and Russian abstracts).

Sapunov, I., Tchoumatchenco, P., Dodekova, L., Černjavska, S. 1985. Contribution to the formal lithostratigraphic scheme related to the Middle Jurassic deposits from Northeast Bulgaria. Review of the Bulgarian Geological Society 46 (2), 144-152 (in Bulgarian, with English abstract).

Sapunov, I., Tchoumatchenco, P., Baburkov, I., Bakalova, D., Dodekova, L., Zheleva, C., Nikolova, M., Černjavska, S. 1986. The Jurassic System in the new boreholes in the area of Provadija. Review of the Bulgarian Geological Society 47 (2), 103-120 (in Bulgarian, with English abstract).

Sapunov, I., Tchoumatchenco, P., Bărdarov, S., Vavilova, M., Dodekova, L., Kitov, P., Černjavska, S. 1986. Stratigraphy of the Jurassic rocks from the borehole sections between the villages of Resen, Veliko Tărnovo Area, and Konak, Tărgovište area. Review of the Bulgarian Geological Society 47 (3), 26-42 (in Bulgarian, with English abstract). 